\begin{tabular}{ll}
\hline \hline MINING AND METALLURGY INSTITUTE BOR & ISSN: 2334-8836 \\
& UDK: 622 \\
\hline \hline
\end{tabular}

UDK: $622.79: 681.33(045)=20$

DOI:10.5937/MMEB1402081R

Radmilo Rajković, Miomir Mikić, Daniel Kržanović*

\title{
REMEDIATION THE TAILING DUMP RTH IN TERMS OF STABILITY ${ }^{* *}$
}

\begin{abstract}
Checking the dam stability of the flotation tailing dump RTH within RTB Bor, it was determined on some analyzed profiles that the stability coefficient has less value than the legally prescribed limits. This work presents the measures for bringing the stability coefficient of dam in prescribed limits to all profiles, as well as checking the stability upon implementation of remedial measures.

Keywords: flotation tailing dump RTH, remediation, stability, Standard SRPS U.C5.020, computer program GeoStudio2007.
\end{abstract}

\section{INTRODUCTION}

The flotation tailing dump RTH within RTB Bor is located southeast of the Flotation Plant Bor. To protect other surfaces from degrading, the existing excavated area of the open pit RTH at depth of $238 \mathrm{~m}$ after completion the operation in 1985 began to be filled with flotation tailings from the Flotation Plant Bor, Figure 1.

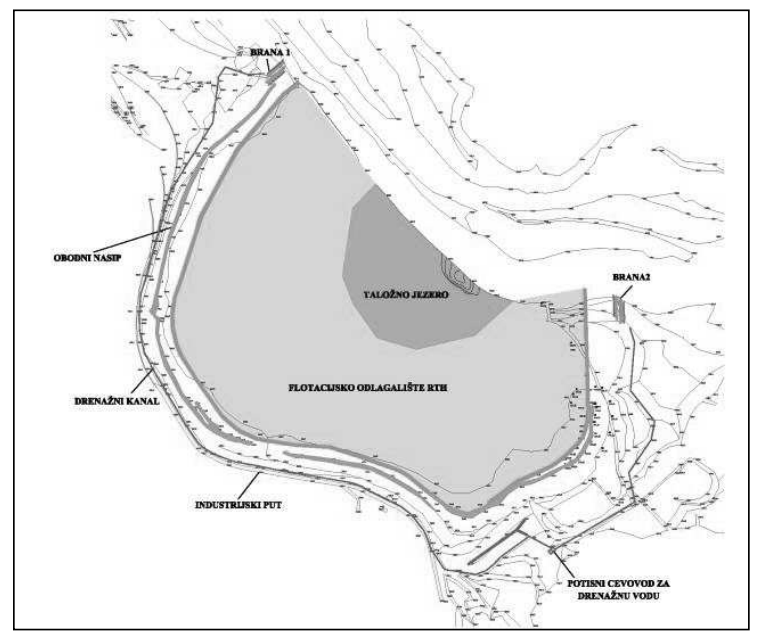

Figure 1 Flotation Tailing Dump RTH

\footnotetext{
* Mining and Metallurgy Institute Bor, radmilo.rajkovic@irmbor.co.rs

** This work is the result of the Project TR37001 "The Impact of Mining Waste from RTB Bor on the Pollution of Surrounding Water Systems with the Proposal of Measures and Procedures for Reduction Harmful Effects on the Environment", funded by the Ministry of Education, Science and Technological Development of the Republic of Serbia
} 
Flotation tailing dump is elliptical in shape with the approximate direction of the main axis east - west. Some expansion of tailing dump was made by the former valley of the Bor River in the direction of NS - SE. This valley is towards NW, i.e. to the landfill of smelter slag that is closed by dam, which was built of hydrocyclone sand. At this point, the dam relies on the high plan and represents the beginning of a semicircular dam around tailing dump.

On the west side, the flotation tailing dump RTH is separated from the flotation tailing dump Bor by peripheral dike of flotation sand. Downstream the former valley of the Bor River is dammed by an embankment, height of about $300 \mathrm{~m}$ and length of about $350 \mathrm{~m}$ from the overburden of the open pit and other waste materials (fly ash from thermal power plant, construction debris - concrete blocks, tires, etc.). A downstream flotation Dam 2 is built on such dike of cyclone sand.

On the east side, the flotation tailing dump relies on high plans of overburden of the open pit Bor.

On the SE side of the tailing dump, is a landfill of the open pit of the ore body " $\mathrm{H"}$. After termination the need to use the haulage road of the open pit "H", the road is dammed of hydrocyclone sand of sand tailings. This dam is the other end of the semi-circular dam formed of hydrocyclone sand of tailings.

Total length of the semi-circular dam is $1700 \mathrm{~m}$ with the mean dam crest elevation of $370 \mathrm{~m}$ above sea level.
Stability of perimeter dike of the tailing dump RTH depends on a position of sediment lake within the accumulation area; If water of sediment lake touches the inner slope of perimeter dike, on the west side of tailing dump, the stability of tailing dump is in question, especially during an earthquake above 8 degrees on the Mercalli scale. [10] Penetration of flotation sludge through the perimeter dike would cause a threat to the industrial road and railway and there would be a spillage of sludge in the Bor River, and a flood wave would endanger the village of Slatina and land and water in the coastal region of the Bor River to Timok, and then the mouth of Timok in Danube. [10]

\section{CURRRENT STATE OF DAM}

Stability calculation was done using the licensed program GeoStudio 2007, its part Slope/W, that is specialized in cases of limit equilibrium [1-3, 5-9]. The calculation was done by the method of Morgenstern - Price. Physical - mechanical parameters of the working environment are taken from [4].

The impact of groundwater on stability is modeled by piezometric water level. The calculation was made for static loads and dynamic loads for occurrence of earthquakes in seismic coefficient $K_{s}=0.05$.

Stability analysis was done using the tool Tool Entry and Exit defining the area in which the sliding plane intersects the surface area and radius area of potential sliding planes, Figure 2.

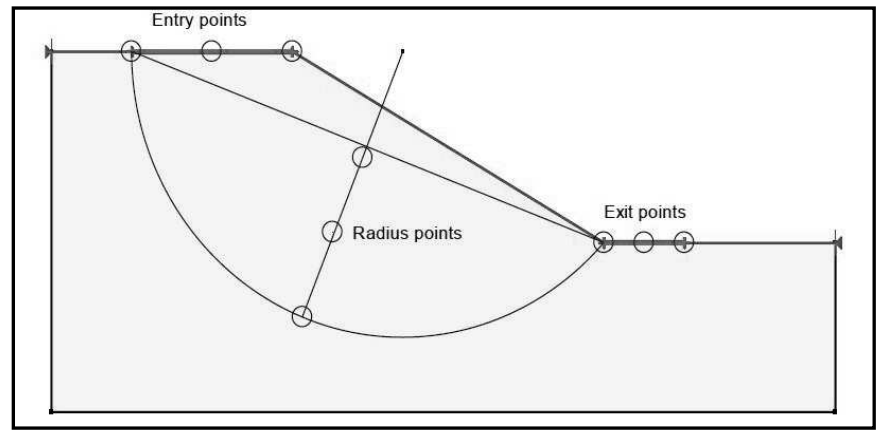

Figure 2 Tool Entry and Exit 
Analysis the stability of flotation tailing dump RTH was done on profiles $2 / 1$, $4 * / 1,6 / 2,7 * / 1$ and 10/1. Position of analyzed profiles is shown in Figure 3. The results of calculations are shown in Table 1.

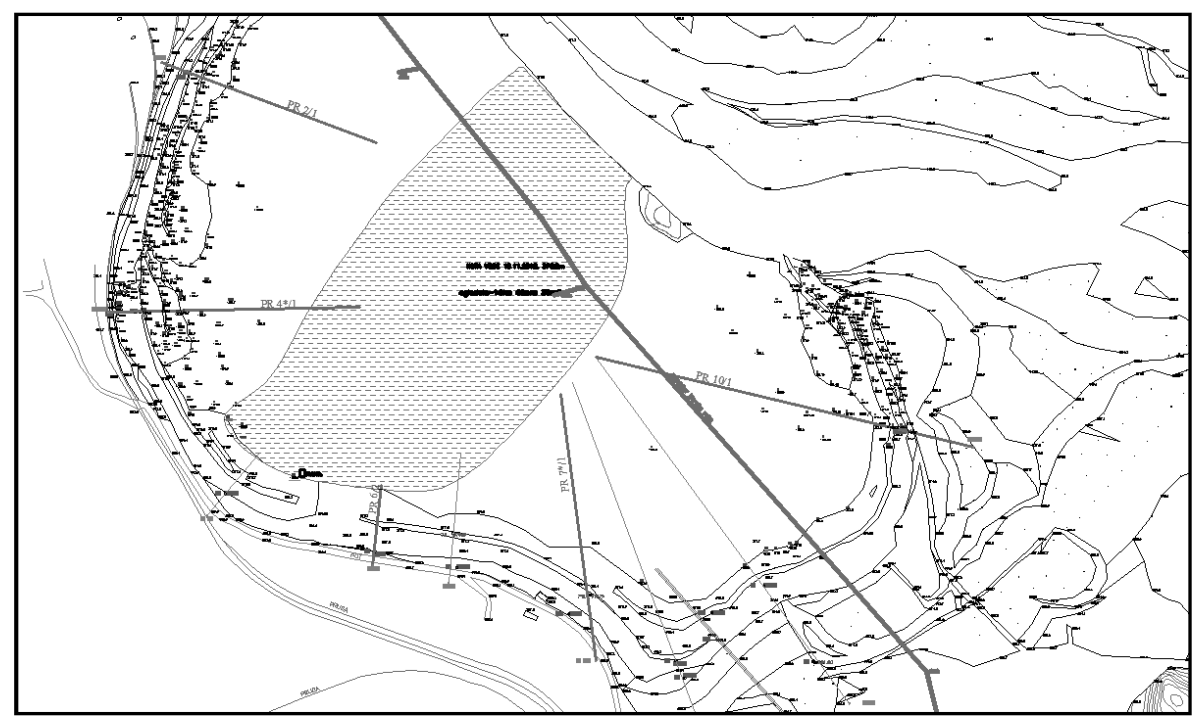

Figure 3 Position of analyzed profiles for stability calculation

Table 1 Summary review of stability coefficient for analyzed profiles

\begin{tabular}{|c|c|c|}
\hline Cross section & F $_{\mathbf{s}}$ static & F $_{\mathbf{s}}$ dynamic \\
\hline $2 / 1$ & 1.210 & 1.059 \\
\hline $4 * / 1$ & 2.076 & 1.685 \\
\hline $6 / 2$ & 1.132 & 1.005 \\
\hline $7 * / 1$ & 1.120 & 0.987 \\
\hline $10 / 1$ & 2.745 & 2.130 \\
\hline
\end{tabular}

Comparing the obtained safety coefficients to the permissible minimum coefficient, prescribed by technical conditions for design of earth dams and hydrotechnical dikes - SRPS U.C5.020 [2], that for the earth dams, height over $15 \mathrm{~m}$, is minimum $\mathrm{F}_{\mathrm{s}}=1.50$ in the case of permanent static load, i.e. $F_{\mathrm{s}}=1.00$ in the case of periodical dynamic load for occurrence of earthquake, the following can be concluded:
On profiles $2 / 1,6 / 2$ and $7 * / 1$, the calculated values of static stability coefficients are below the prescribed limit of 1.50 ;

$>$ On profiles $6 / 2$ and $7 * / 1$, the calculated values of dynamic stability coefficients are on the limit of 1.00 .

Based on the above, the conclusion is that remediation measures have to be implemented in critical areas of dams on the flotation tailing dump RTH. 


\section{REMEDIATION MEASURES}

In order to bring the dike into a stable state the following remedial measures should be taken as follows:

1. Achieving the stability of dike on tailings dump RTH by formation the beaches between the dike and water. Beach is formed by settling of larger particles immediately after hydro-cycloning. Beach width is determined by calculation the stability of dike. The existence of beach increases the safety coefficient of dam, dikes, due to lowering the level of leachate through the dike itself. By stability calculation of dike, it was found that the distance of water mirror from the inside base of a dike must not be less than $150 \mathrm{~m}$.

2. In order to allow the formation of beach, it is necessary to relocate the pumping station PPS1 from present to designed location. Its relocation will reduce the water level in the accumulation lake, allowing the formation of beach with larger width, which directly leads to reduction in the level of leachate in piezometers. Increasing the beach width in the area of Dam 2 will lead to reduction in the level of leachate in the extended profile $9 / 1$.

3. In order to control the amount of water in accumulation lake, the following is needed:

$>$ To reduce the flow of storm water that gravitate from catchment areas of higher plan, and which is achieved by making the protective perimeter channels on a high plan;

$>$ To maintain the equipment for prepumping the return process water with PPS in the working order. Due to the unplanned failures, longer delays of pump operation may be caused which will result in inability of pumping the process water due to which the water level increase in the accumulation lake. The increase in water level will come due to the introduction of additional fresh water lake in the flotation process of copper minerals. In this connection, it is necessary to plan the regular service interventions and provision of spare parts and consumables for pumps and generators.

4. Until a beach has minimum width of $150 \mathrm{~m}$, it is more likely to control the leachate levels in piezometers, at least once a week and to test the stability of dams and dikes once a month. If anomalies are detected in operation of piezometers, it is required to do the stability checking for observed profiles. Considering the importance of piezometers, it is necessary to maintain all piezometers in correct and functional condition.

5. It is necessary to monitor constantly any changes on dams: occurrences of cracks, landslides and subsidences, as well as the occurrence of influx water.

6. In a part of dikes and dams where the dike height and its geometry (northwestern and western part of the tailing dump) are threatened due to the effects of wind erosion), it is necessary, as the operating conditions are created for this, it is necessary to bring the geometry of dike to the designed conditions (incline of the outer slope of 1:3 and the incline of the inner slope of 1:2.5).

7. It is necessary, as soon as possible to build the missing part of the dike (towards high plan) in length of about $40 \mathrm{~m}$, with the aim of connecting the dike and plan. 
8. After correction the dike geometry in order to prevent re-distortion of the dike crest, due to the effects of wind erosion, a humus layer (up to $10 \mathrm{~cm}$ ) has to be applied in order to prevent the effect of wind and blowing of fine sand particles.

9. Monitor the water level in the accumulation so as to comply with the rule that the water level in the lake is lower by $3 \mathrm{~m}$ from elevation of the tailing dump dike, which provides a retention space for water reception in the event of catastrophic rainfall of $1500000 \mathrm{~m}^{3}$.

\section{CONDITION OF DAM AFTER REALIZATION THE REMEDIATION MEASURES}

The results of calculations using the computer program GeoStudio 2007 [1-3, 59] on critical sections $2 / 1,6 / 2$ and $7 * / 1$ after implementation of remediation measures, are shown in Figures: 4 - 9 and in Table 2.

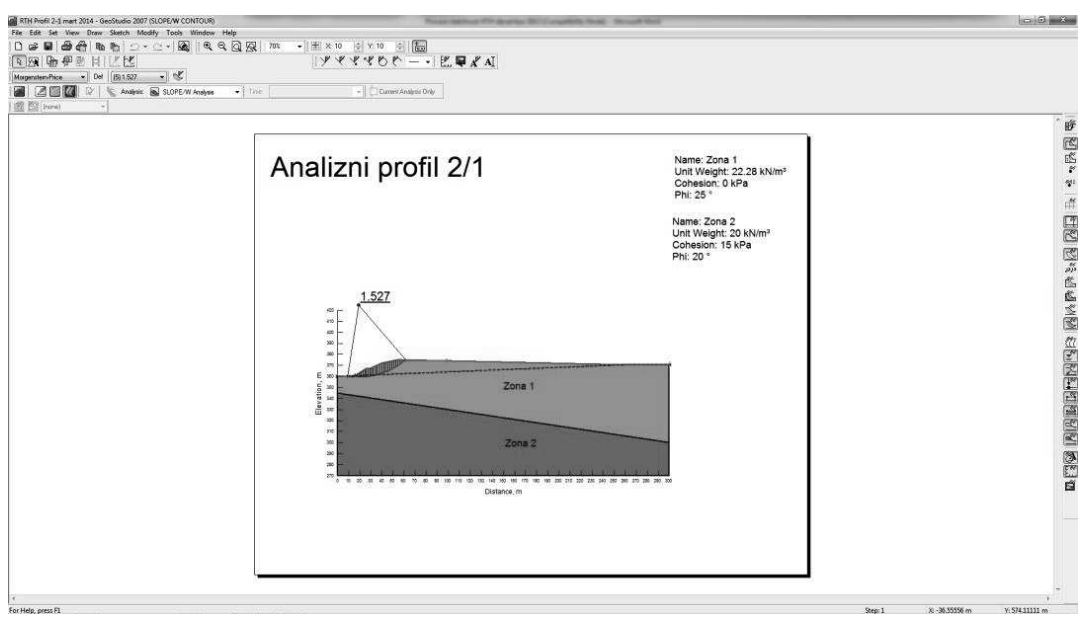

Figure 4 Stability coefficient per profile 2/1 for static loads

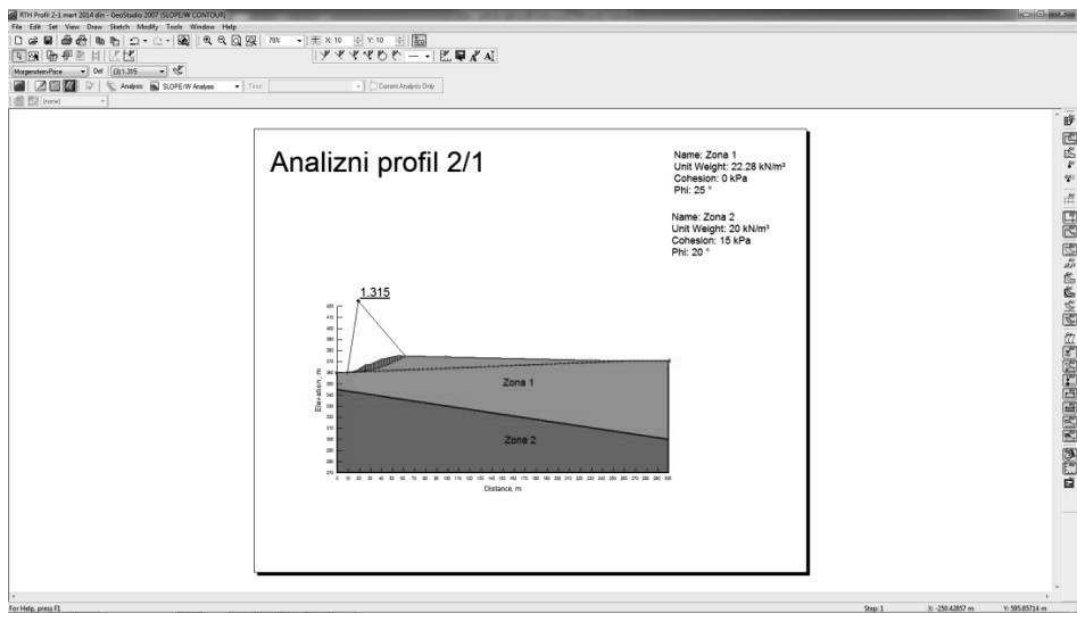

Figure 5 Stability coefficient per profile 2/1 for dynamic loads 


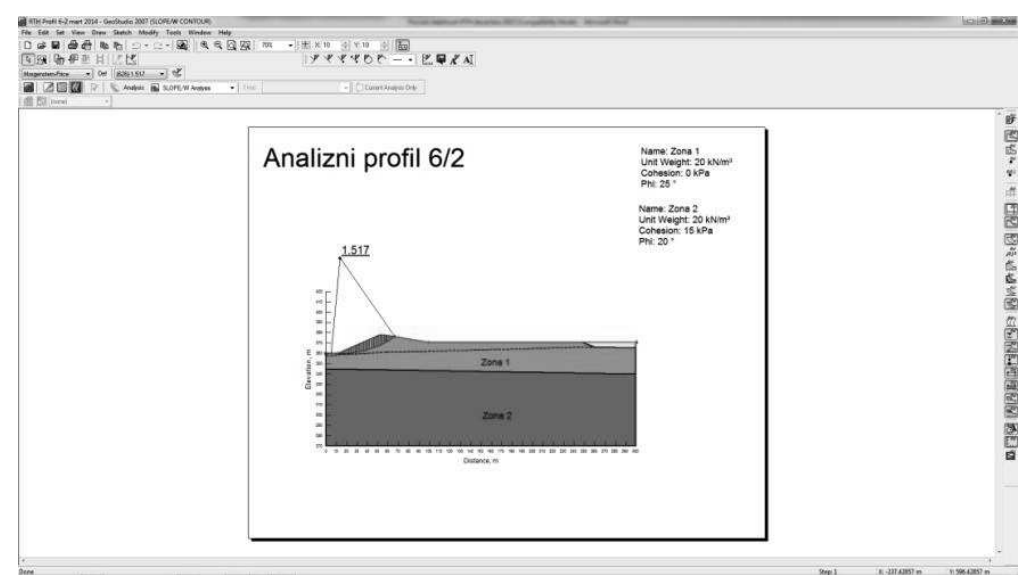

Figure 6 Stability coefficient per profile $6 / 2$ for static loads

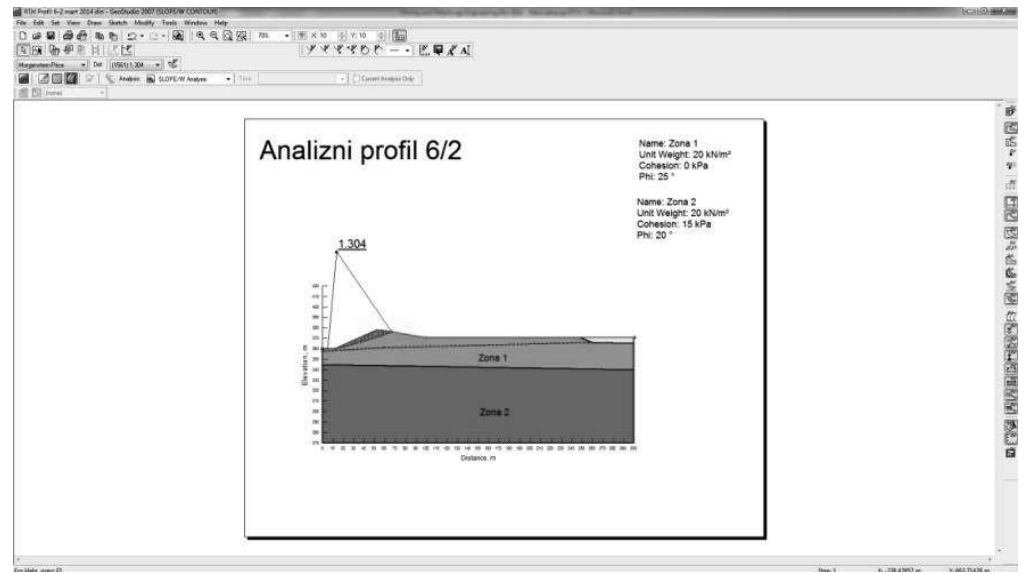

Figure 7 Stability coefficient per profile 6/2 for dynamic loads

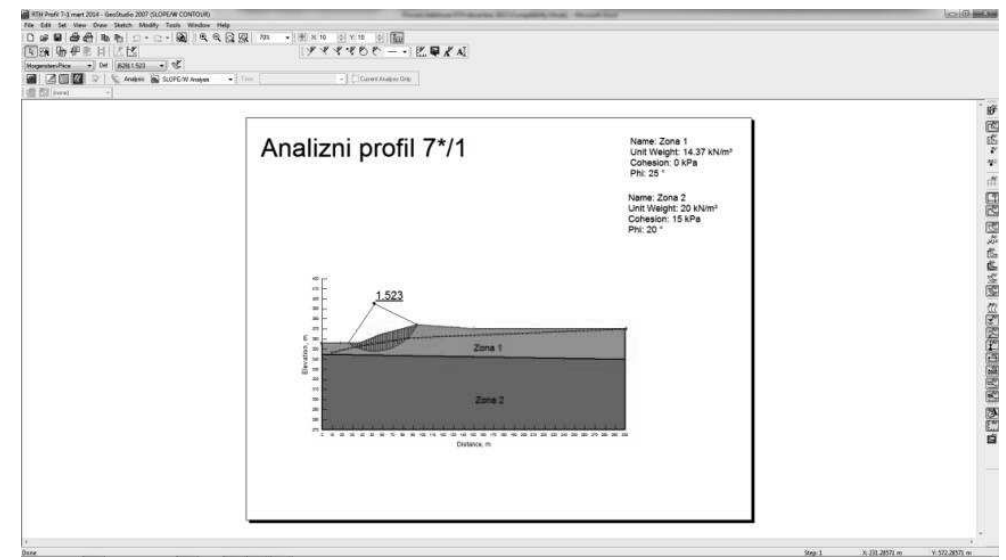

Figure 8 Stability coefficient per profile $7 * / 1$ for static loads 


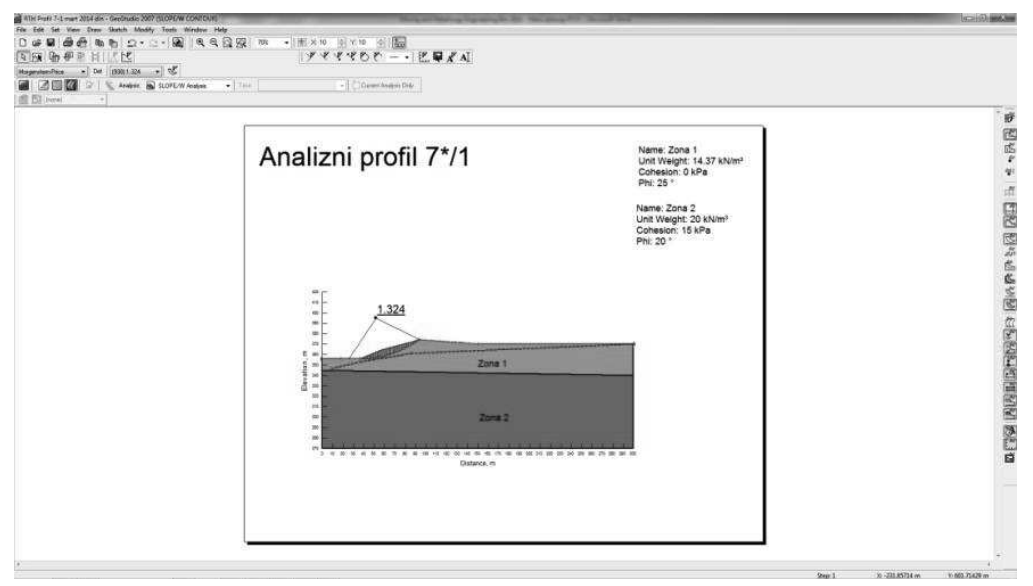

Figure 9 Stability coefficient per profile 7*/1 for dynamic loads

Table 2 Summary review of stability coefficients after remedial measures

\begin{tabular}{|c|c|c|}
\hline Cross section & $\mathrm{F}_{\mathrm{s}}$ static & $\mathrm{F}_{\mathrm{s}}$ dynamic \\
\hline $2 / 1$ & 1.527 & 1.315 \\
\hline $6 / 2$ & 1.517 & 1.304 \\
\hline $7 * / 1$ & 1.523 & 1.324 \\
\hline
\end{tabular}

\section{CONCLUSION}

After implementation of remedial measures on the flotation tailing dump RTH in order to bring the static and dynamic coefficients of dam stability in the statutory limits, all coefficients of stability by analyzed profiles have acceptable values.

A great help in determining the distance of water mirror from the dam crest is the use of computer program GeoStudio 2007. Through this SOFTVEA performed

A variation of piezometric water level by analyzed profiles was carried out using this software until minimum required distance of water mirror was determined for which the stability coefficients are satisfactory.

Designed condition of the tailing dump dam, the use of measures to reduce the amount of accumulation water, maintenance of equipment for pre-pumping the return process water, as well as monitoring any changes on dams in order to timely response are very important for stability.

\section{REFERENCES}

[1] R. Rajković, M. Bugarin, V. Marinković: Stability Analysis of the Waste Dump "Oštreljski planir" of the Open Pit "Bor" in a Function of Water Quantity, Mining and Metallurgy Engineering Bor, 3/2013, pp. 49-64.

[2] R. Rajković, D. Kržanović, M. Mikić, Vladan Marinković: Stability of Ash and Slug Dump on Thermal Power Plant Gacko with Software Geostudio 2007; pp. 227-231; Mining 2013 Plans for Development and Improvent of Mining; Veliko Gradište, Srebrno jezero 28-31 May 2013.

[3] J. N. Stanković, S. Filipović, R. Rajković, Lj. Obradović, V. Marinković, R. Kovačević: Risk and Reliability Analysis of Slope Stability-Deterministic and Probabilistic Method; $17^{\text {th }}$ International Research/Expert Conference: "Trends in the Development of 
Machinery and Associated Technology"; 10-11 September 2013 Istanbul Turkey Year 17 No. 1; pp. 229-232.

[4] Report on Technical Monitoring of High Dams 1 and 2 and Peripheral Dam of the Flotation Tailing Dump of the Flotation Plant Bor"; Faculty of Mining and Geology Belgrade, 2012;

[5] M. Ignjatović, S. Ignjatović, M. Negovanović, R. Rajković, L. Djurdjevac Ignjatović, D. Ignjatović: Determination the Final Slope Angle of the Open Pit Mine During Exploitation of Oil Shale from Aleksinac Deposit Using the GeoStudio2007 - SLOPE/W Program; TTEM - Technics Technologies Education Management 2011/3; pp. $615-621$;

[6] M. Ignjatović, R. Rajković, B. Rajković, D. Milanović, M. Popović; Stability Analysis of the Open Pit "Progorelica" by Bishop Method and Program Plan Failure Analysis; II International Symposium "Mining 2011" Mining Present State and Future Prospects and Sustainable Develop-ment; Vrnjačka banja 10 13 May 2011; pp. 599 - 603;
[7] M. Ignjatović, R. Rajković, M. Maksimović, D. Ignjatović: Technical Solution: Determination the Final Angles of the Newly-Designed Open Pit in the Exploitation of Shales from the Site of the Aleksinac Deposit Using the Program GeoStudio 2007 - Slope/W, Proct MSTD TR-17005 TR-1, MMI Bor No. 543, 2010;

[8] R. Rajković, D. Kržanović, R. Lekovski: Stability Analysis of Inner Waste Dump "Kutlovaca" of the Coal Open Pit Mine "Potrlica"- Pljevlja Using the GeoStudio 2007 Software; Mining Engineering 1/2010; pp. $69-80$;

[9] R. Rajković, D. Kržanović, B. Rajković: Analysis of Stability During the Cleaning of Cassettes 1 and 2 of Settling Pond Filter of Waste Water Purification Facilities of Kolubara Prerada Vreoci by Software Geostudio 2007; 42 ${ }^{\text {nd }}$ International October Conference on Mining and Metallurgy; pp. 33-40, 2010;

[10] R. Lekovski, M. Mikić, D. Kržanović; Impact of the Flotation Dumps on the Living Environment of Bor and Protective Measures; Mining and Metallurgy Engineering Bor, 2/2013, pp. 97-106. 


\begin{tabular}{ll}
\hline \hline INSTITUT ZA RUDARSTVO I METALURGIJU BOR & ISSN: 2334-8836 \\
& UDK: 622 \\
\hline \hline
\end{tabular}

Radmilo Rajković, Miomir Mikić, Daniel Kržanović*

\section{SANACIJA FLOTACIJSKOG JALOVIŠTA RTH SA ASPEKTA STABILNOSTI ${ }^{* *}$}

\section{Izvod}

Proverom stabilnosti brane flotacijskog jalovišta RTH u sastavu RTB Bor, utvrđeno je da na pojedinim analiznim profilima koeficijent stabilnosti ima manje vrednosti od zakonski propisanih granica. $U$ ovom radu prikazane su mere za dovođenje koeficijenta stabilnosti brane u propisane granice na svim profilima, kao i provera stabilnosti nakom realizacije sanacionih mera.

Ključne reči: flotacijsko jalovište RTH, sanacija, stabilnost, Standard SRPS U.C5.020, računarski program GeoStudio2007

\section{UVOD}

Flotacijsko jalovište RTH, koje je u sklopu RTB Bor se nalazi jugoistočno od Flotacije Bor. Radi zaštite drugih površina od degradiranja, postojeći otkopni prostor površinskog kopa RTH dubine $238 \mathrm{~m}$ posle završetka eksploatacije 1985. godine počeo je da se zapunjava flotacijskom jalovinom iz Flotacije Bor, slika 1.

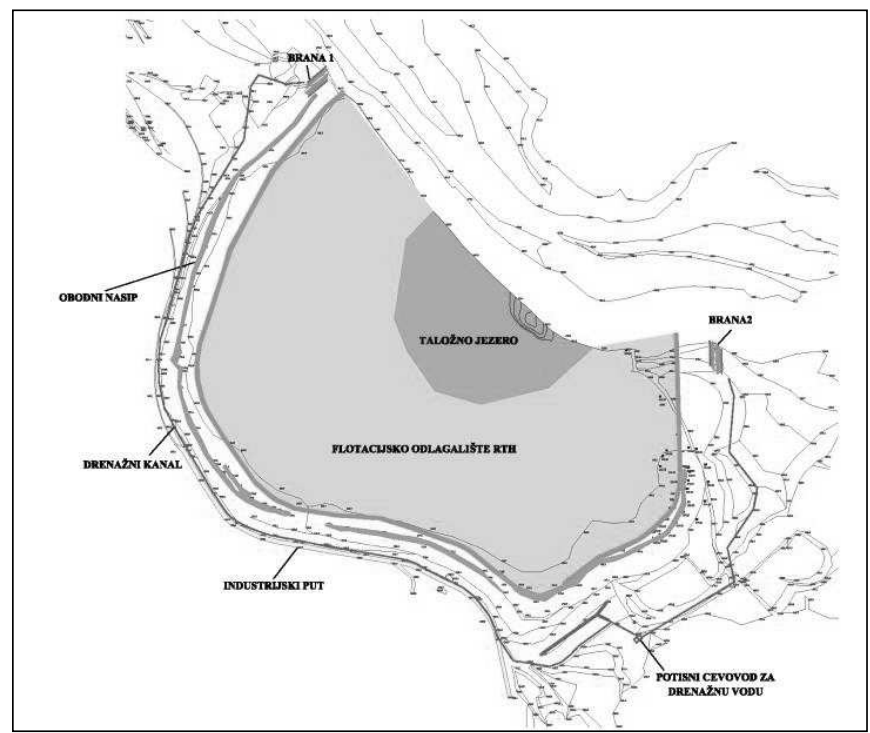

SI. 1. Flotacijsko jalovište RTH

\footnotetext{
* Institut za rudarstvo i metalurgiju Bor, radmilo.rajkovic@irmbor.co.rs

** Ovaj rad je proistekao iz projekta TR37001 „Uticaj rudarskog otpada iz RTB Bor na zagađenje vodotokova, sa predlogom mera i postupaka za smanjenje štetnog dejstva na životnu sredinu “, koji je finansiran sredstvima Ministarstva prosvete, nauke i tehnološkog razvoja Republike Srbije
} 
Flotacijsko jalovište ima oblik elipse sa približnim pravcem glavne ose istok - zapad. Izvesno proširenje jalovišta je izvršeno bivšom dolinom Borske reke u pravcu SJ - JI. Ova dolina je prema SZ tj. prema odlagalištu topioničke šljake zatvorena branom koja je izgrađena od peska hidrociklona. $\mathrm{Na}$ tom mestu brana se naslanja na visoki planir i predstavlja početak polukružne brane oko jalovišta.

Na zapadu flotacijsko jalovište RTH je od flotacijskog jalovišta Bor, odvojeno obodnim nasipom od flotacijskog peska. Nizvodno bivša dolina Borske reke je pregrađena nasipom visine oko $300 \mathrm{~m}$ i dužine oko $350 \mathrm{~m}$ od raskrivke sa kopa i drugog otpadnog materijala (pepela iz termoelektrane, građevinskog šuta - betonskih blokova, auto guma i drugo). Na ovakvom nasipu izgrađenja je nizvodna flotacijska brana 2 od ciklonskog peska.

$\mathrm{Na}$ istočnoj strani flotacijsko jalovište oslanja se na visoke planire raskrivke površinskog kopa Bor.

Sa JI strane jalovišta, nalazi se odlagalište površinskog kopa rudnog tela "H". Nakon prestanka potrebe za korišćenjem izvoznog puta površinskog kopa "H", put je pregrađen branom od hidrociklonskog peska jalovine. Ova brana predstavlja drugi kraj polukružne brane koja je formirana od hidrocikloniranog peska jalovine.

Ukupna dužina polukružne brane iznosi $1700 \mathrm{~m}$ sa srednjom kotom krune brane $370 \mathrm{mnv}$.
Stabilnost obodnog nasipa FJ RTH zavisi od položaja taložnog jezera unutar akumulacionog prostora. Ukoliko vode taložnog jezera dodiruju unutrašnju kosinu obodnog nasipa na zapadnoj strani jalovišta, stabilnost jalovišta je dovedena u pitanja, a naročito za vreme zemljotresa iznad 8 stepeni Merkalijeve skale. [10] Prodor flotacijskog mulja kroz obodni nasip izazvao bi ugrožavanje industrijskog puta $\mathrm{i}$ industrijske pruge $\mathrm{i}$ došlo bi do izlivanja mulja u Borsku reku, a poplavni talas bi ugrozio selo Slatinu i zemljište i vode u priobalju Borske reke do Timoka, a zatim i ušće Timoka u Dunav. [10]

\section{POSTOJEĆE STANJE BRANE}

Proračun stabilnosti je rađen licenciranim programom GeoStudio 2007, odnosno njegovim delom Slope/W, koji je specijalizovan za slučajeve granične ravnoteže [1-3, 5-9]. Proračun je rađen po metodi Morgenstern - Price. Fizičko - mehanički parametri radne sredine preuzeti su iz [4].

Uticaj podzemnih voda na stabilnost modeliran je piezometrijskim nivoom vode. Proračun je rađen za statička opterećenja i dinamička opterećenja za pojavu zemljotresa za koeficijent seizmike $\mathrm{K}_{\mathrm{s}}=0,05$.

Analiza stabilnosti rađena je alatom Entry and Exit kojim se definiše oblast $u$ kojoj klizna ravan seče površinu terena i oblast radijusa potencijalnih kliznih ravni, slika 2.

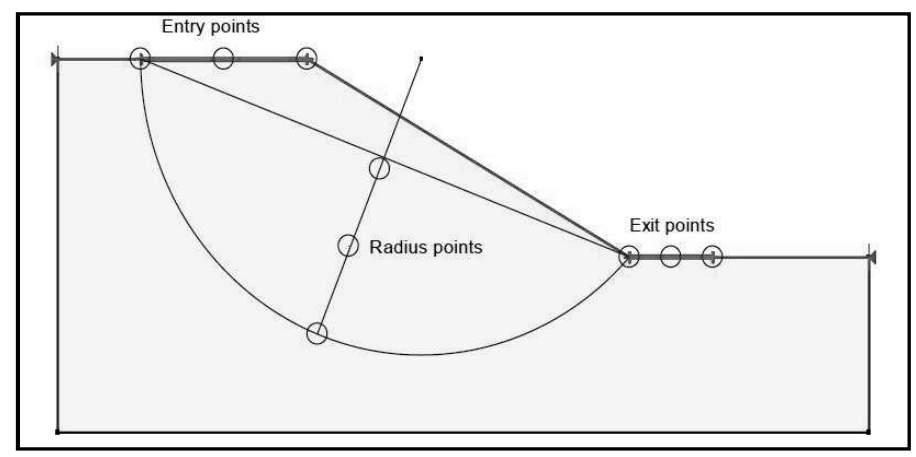

S1. 2. Alat Entry and Exit 
Analiza stabilnosti flotacijskog jalovišta RTH vršena je na profilima $2 / 1,4 * / 1,6 / 2,7 * / 1$ i 10/1. Položaj analiznih profila prikazan je na slici 3 . Rezultati proračuna prikazani su u tabeli 1 .

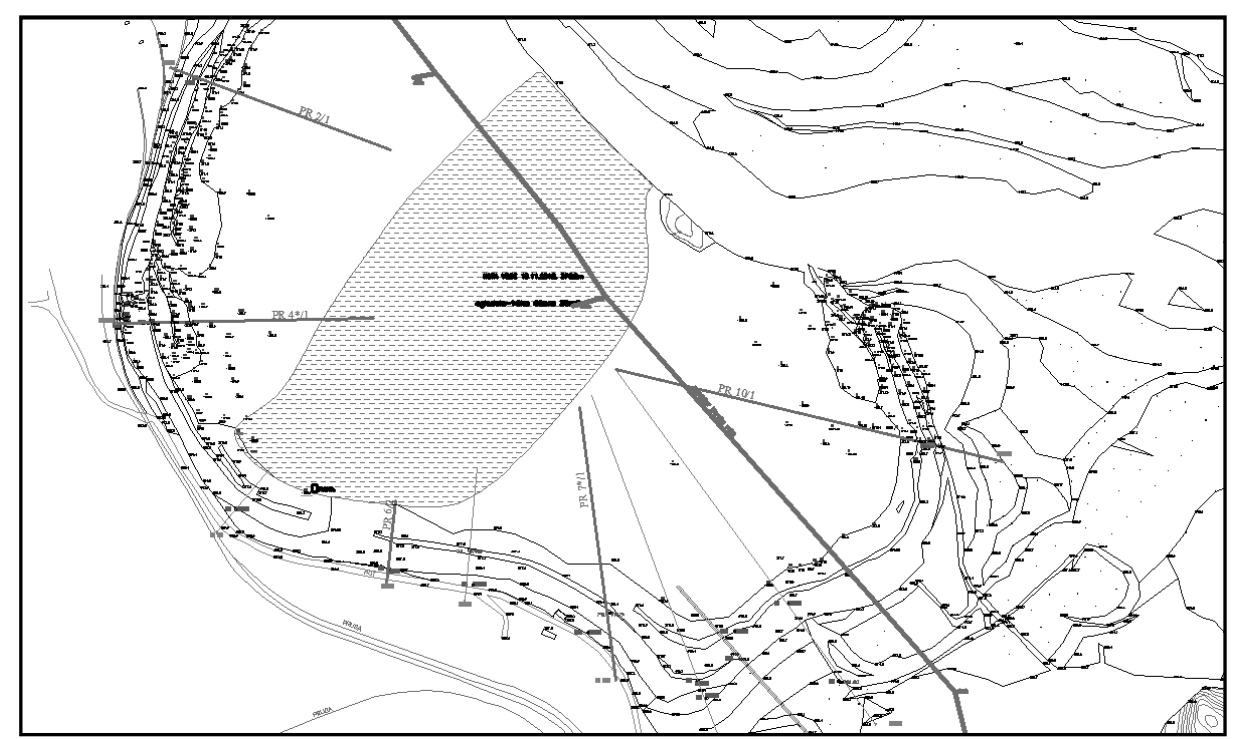

SI. 3. Položaj analiznih profila za proračun stabilnosti

Tabela 1. Zbirni pregled koeficijenta stabilnosti za analizne profile

\begin{tabular}{|c|c|c|}
\hline Profil & F $_{\mathbf{s}}$ statički & F $_{\mathbf{s}}$ dinamički \\
\hline $2 / 1$ & 1,210 & 1,059 \\
\hline $4 * 1$ & 2,076 & 1,685 \\
\hline $6 / 2$ & 1,132 & 1,005 \\
\hline $7 * 1$ & 1,120 & 0,987 \\
\hline $10 / 1$ & 2,745 & 2,130 \\
\hline
\end{tabular}

Upoređenjem dobijenih koeficijenata sigurnosti sa dozvoljenim minimalnim koeficijentom, propisanim tehničkim uslovima za projektovanje nasutih brana i hidrotehničkih nasipa - SRPS U.C5.020 [2], koji za nasute brane visine preko $15 \mathrm{~m}$ iznosi minimalno $\mathrm{F}_{\mathrm{s}}=1,50 \mathrm{u}$ slučaju stalnog statičkog opterećenja, odnosno $F_{s}=1,00 \mathrm{u}$ slučaju povremenog dinamičkog opterećenja za pojavu zemljotresa, može da se zaključi sledeće:
Na profilima 2/1, 6/2 i 7*/1 proračunate vrednosti statičkih koeficijenata stabilnosti su ispod propisane granice od 1,50 ;

Na profilima $6 / 2$ i $7 * / 1$ proračunate vrednosti dinamičkhi koeficijenata stabilnosti su na granici od 1,00.

$\mathrm{Na}$ osnovu navedenog zaključak je da se obavezno moraju sprovesti mere sanacije na kritičnim delovima brana flotacijskog jalovišta RTH. 


\section{MERE SANACIJE}

$\mathrm{U}$ cilju dovođenja nasipa u stabilno stanje kao mere sanacije treba se preduzeti sledeće:

1. Postizanje stabilnosti nasipa na jalovištu RTH, formiranjem plaža između nasipa i vode. Plaža nastaje istaložavanjem krupnijih čestica neposredno posle hidrocikloniranja. Širina plaže se određuje proračunom stabilnosti nasipa. Postojanjem plaže povećava se koeficijent sigurnosti brane, nasipa, usled sniženja nivoa procednih voda kroz sam nasip. Proračunom stabilnosti nasipa utvrđeno je da udaljenje vodenog ogledala od unutrašnje nožice nasipa ne sme biti manje od $150 \mathrm{~m}$.

2. Da bi se omogućilo formiranje plaža, neophodno je preseliti pumpnu stanicu PPS1 sa sadašnje na projektovanu lokaciju. Njenim preseljenjem smanjiće se nivo vode u akumulacionom jezeru, što omogućava formiranje plaža veće širine što direktno dovodi do smanjenja nivoa procednih voda u pijezometrima. Povećanje širine plaže u zoni brane 2 dovešce do smanjenja nivoa procednih voda na produženom profilu 9/1.

3. U cilju kontrole količine vode $\mathrm{u}$ akumulacionom jezeru, potrebno je:

> smanjiti priliv atmosferskih voda koje gravitiraju sa slivnih površina visokog planira, a koje se postiže izradom zaštitnih obodnih kanala na visokom planiru;

> održavanje opreme za prepumpavanje povratne tehnološke vode sa PPS u funkcionalnom stanju. Usled neplaniranih kvarova, može doći do dužeg zastoja rada pumpi što će imati za posledicu, nemogućnost ispumpavanja tehnološke vode usled čega se povećava nivo vode $\mathrm{u}$ akumulacionom jezeru. Do porasta nivoa vode doći će usled dodatnog uvođenja sveže jezerske vode $\mathrm{u}$ proces flotiranja minerala bakra. S tim u vezi potrebno je planirati redovne servisne intervencije i nabavku rezervnih delova i potrošnog materijala za pumpe $\mathrm{i}$ agregate.

4. Dok se ne postigne plaža minimalne širine od $150 \mathrm{~m}$, potrebno je češće kontrolisati nivoe procednih voda $\mathrm{u}$ pijezometrima, minimalno jednom nedeljno kao i vršiti proveru stabilnosti brana i nasipa jednom mesečno. Ukoliko se primete anomalije u radu pijezometara obavezno uraditi proveru stabilnosti za uočene profile. Obzirom na važnost pijezometara neophodno je održavati sve pijezometre $\mathrm{u}$ ispravnom i funkcionalnom stanju.

5. Potrebno je stalno praćenje eventualnih promena na branama: pojave pukotina, klizišta i sleganja, kao i pojava provirnih voda.

6. U delu nasipa i brana gde je usled dejstva erozije vetra ugrožena visina nasipa kao i njegova geometrija (severozapadni i zapadni deo jalovišta), potrebno je čim se za to stvore operativni uslovi dovesti geometriju nasipa na projektovano stanje (nagib spoljašnje kosine 1:3 i nagib unutrašnje kosine 1:2,5).

7. Neophodno je u što kraćem roku izgraditi nedostajući deo nasipa (prema visokom planiru) u dužini od oko $40 \mathrm{~m}$, sa ciljem spajanja nasipa i planira.

8. Nakon korekcije geometrije nasipa u cilju sprečavanja ponovnog narušavanja krune nasipa, usled dejstva erozije vetra treba naneti sloj humusa (do $10 \mathrm{~cm}$ ), kako bi se sprečilo dejstvo vetra i raznošenje finih čestica peska.

9. Pratiti nivo vode $\mathrm{u}$ akumulaciji tako da se ispoštuje pravilo da nivo 


\section{STANJE BRANE NAKON REALIZACIJE SANACIONIH MERA}

vode $\mathrm{u}$ jezeru bude manji za $3 \mathrm{~m}$ od kote nasipa jalovišta, čime se obezbeđuje retenzioni prostora za prihvat voda u slučaju katastrofalnih padavina od $1.500 .000 \mathrm{~m}^{3}$.
Rezultati proračuna računarskim programom GeoStudio 2007 [1-3, 5-9] na kritičnim profilima $2 / 1,6 / 2$ i $7 * / 1$ nakon sprovođenja sanacionih mera prikazani su na slikama $4-9$ i u tabeli 2.

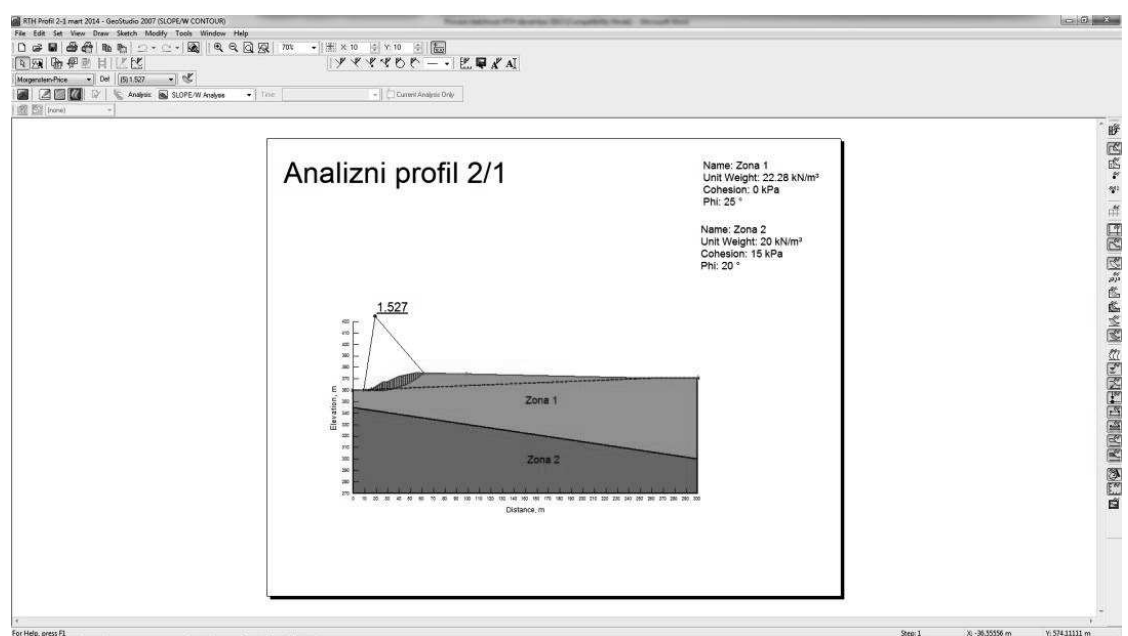

SI. 4. Koeficijent stabilnosti po profilu 2/1 za statička opterćenja

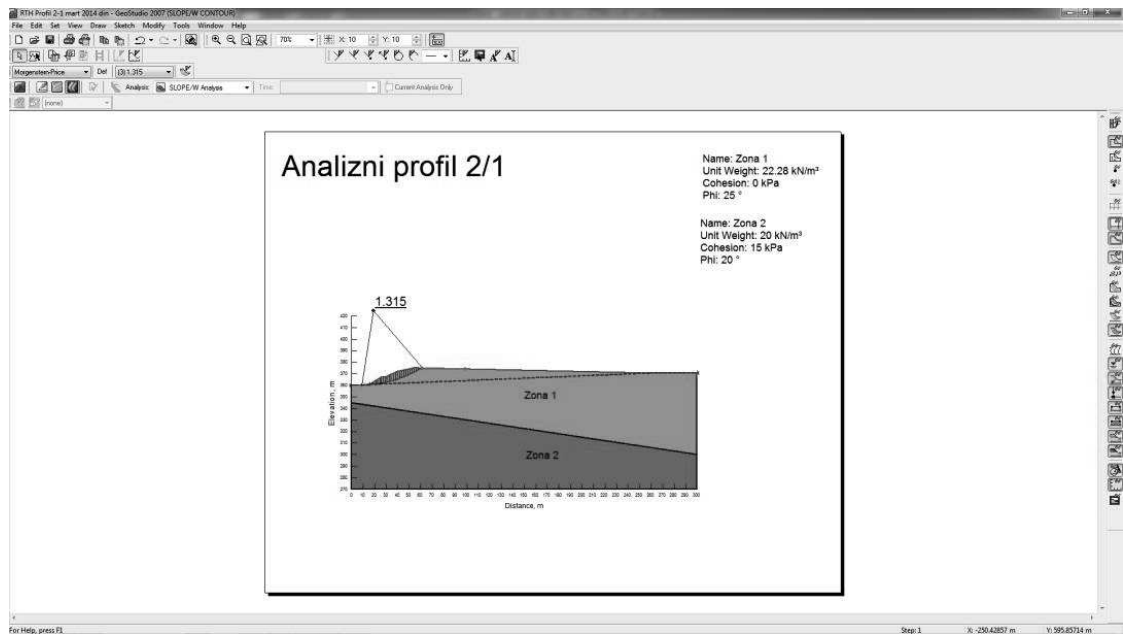

Sl. 5. Koeficijent stabilnosti po profilu 2/1 za dinamička opterćenja 


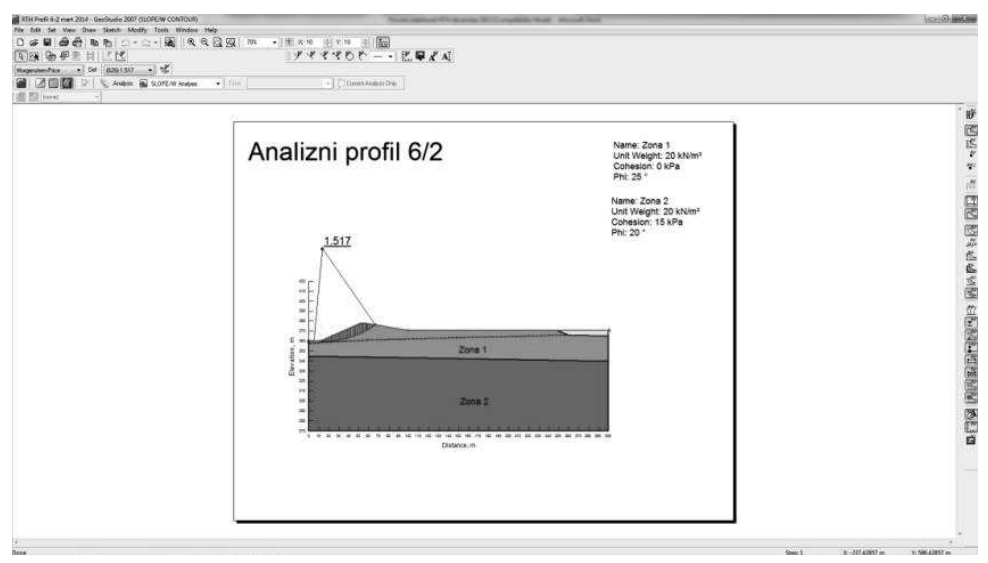

SI. 6. Koeficijent stabilnosti po profilu $6 / 2$ za statička opterćenja

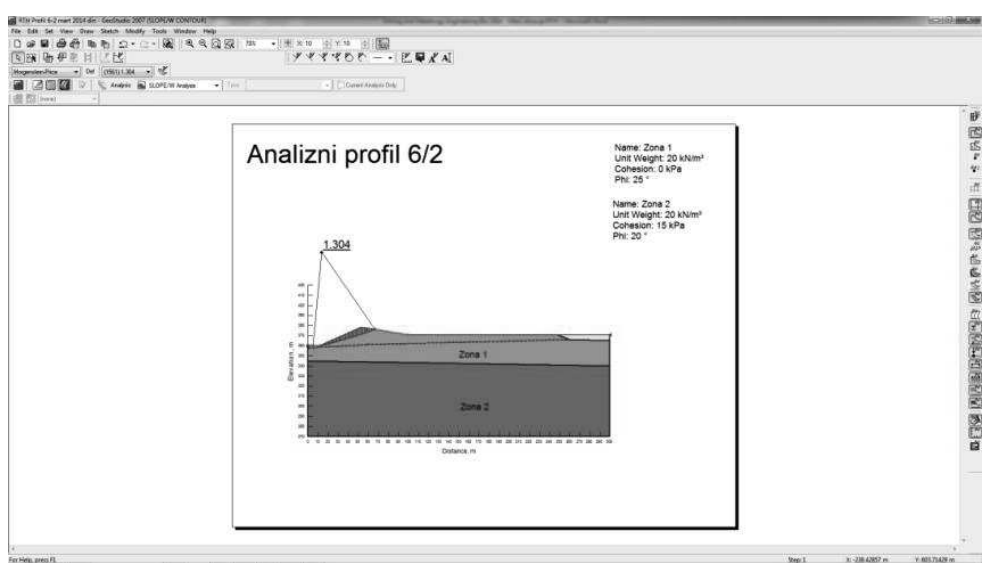

Sl. 7. Koeficijent stabilnosti po profilu $6 / 2$ za dinamička opterćenja

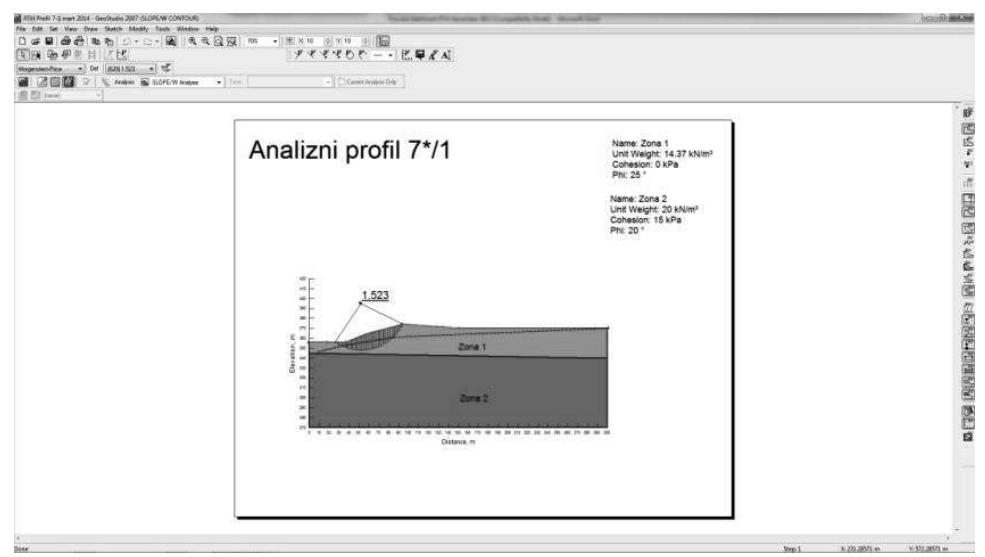

SI. 8. Koeficijent stabilnosti po profilu $7 * / 1$ za statička opterćenja 


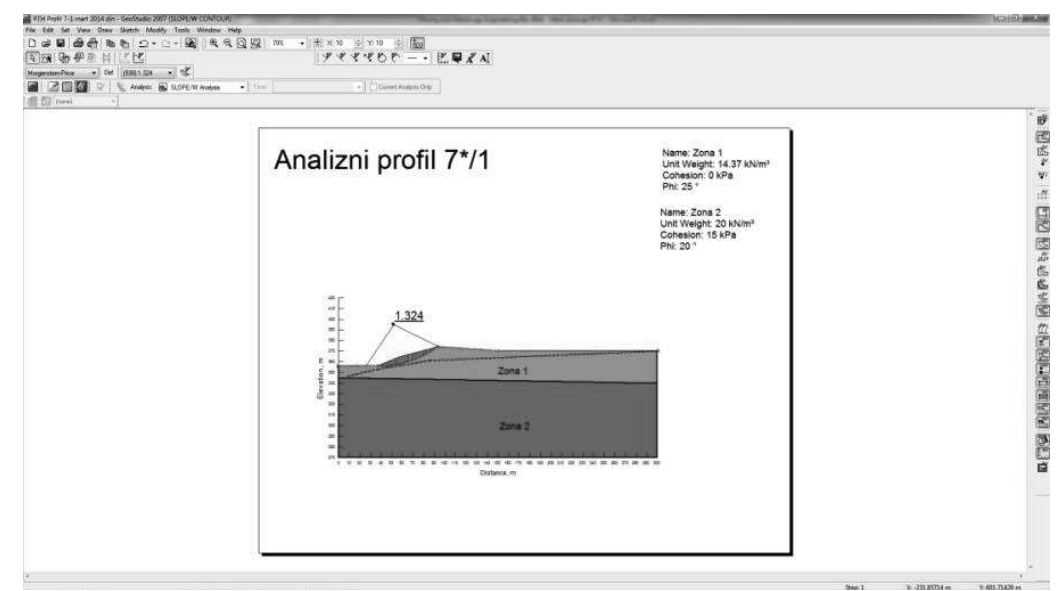

SI. 9. Koeficijent stabilnosti po profilu $7 * / 1$ za dinamička opterćenja

Tabela 2. Zbirni pregled koeficijenta stabilnosti nakon sanacionih mera

\begin{tabular}{|c|c|c|}
\hline Profil & $\mathbf{F}_{\mathbf{s}}$ statički & $\mathbf{F}_{\mathbf{s}}$ dinamički \\
\hline $2 / 1$ & 1,527 & 1,315 \\
\hline $6 / 2$ & 1,517 & 1,304 \\
\hline $7^{* / 1}$ & 1,523 & 1,324 \\
\hline
\end{tabular}

\section{ZAKLJUČAK}

Nakon sprovođenja sanacionih mera na flotacijskom jalovištu RTH u cilju dovođenja statičkih i dinamičkih koeficijenata stabilnosti brane u zakonski propisane granice, svi koeficijenti stabilnosti po analiznim profilima imaju zadovoljavajuće vrednosti.

Velika pomoć pri određivanju udaljenosti vodenog ogledala od krune brane je upotreba računarskog programa GeoStudio 2007. Uz pomoć ovog softvea vršena je varijacija piezometrijskog nivoa vode po analiznim profilima sve dok nije utvrđena minimalna razdaljina vodenog ogledala za koju su koeficijenti stabilnosti zadovoljavajući.

Od izuzetne važnosti za stabilnost je dovođenje brane jalovišta u projektovano stanje, primena mera za smanjenje količine akumulacione vode, održavanje opreme za prepumpavanje povratne tehnološke vode, kao i praćenje eventualnih promena na branama u cilju pravovremenog reagovanja.

\section{LITERATURA}

[1] R. Rajković, M. Bugarin, V. Marinković: Analiza stabilnosti odlagališta jalovine "Oštreljski planir" površinskog kopa "Bor" u funkciji ovodnjenosti, Mining and Metallurgy Engineering Bor, 3/2013, str. 57-64.

[2] R. Rajković, D. Kržanović, M. Mikić, V. Marinković: Stability of Ash and Slug Dump on Thermal Power Plant Gacko with Software Geostudio 2007; str. 227-231; Mining 2013, Plans for development and improvent of mining; Veliko Gradište, Srebrno jezero 28-31 maj 2013. 
[3] J. N. Stanković, S. Filipović, R. Rajković, Lj. Obradović, V. Marinković, R. Kovačević: Risk and Reliability Analysis of Slope Stability-Deterministic and Probabilistic Method; $17^{\text {th }}$ International Research/Expert Conference: "Trends in the Development of Machinery and Associated Technology"; 10-11 September 2013, Istanbul, Turkey Year 17 No 1; str. 229-232

[4] Izveštaj o tehničkom osmatranju visokih brana 1 i 2 i obodne brane flotacijskog jalovišta pogona Flotacija Bor"; Rudarsko - geološki fakultet Beograd, 2012.

[5] M. Ignjatović, S. Ignjatović, M. Negovanović, R. Rajković, L. Đurđevac Ignjatović, D. Ignjatović: Determination of the Final Slope Angle of the Open Pit Mine During Exploitation of Oil Shale from Aleksinac Deposit During GeoStudio2007 - SLOPE/W program; TTEM - Technics Technologies Education Management 2011/3; str. 615 - 621 .

[6] M. Ignjatović, R. Rajković, B. Rajković, D. Milanović, M. Popović: Stability Analysis off Open Pit „Progorelica" by Bishop Method and Program Plan Failure Analysis; II International Symposium „Mining 2011“ Mining Presents State and Future Prospects and Sustainable Development; Vrnjačka banja 10 - 13 maj 2011; str. 599 603.

[7] M. Ignjatović, R. Rajković, M. Maksimović, D. Ignjatović: Tehničko rešenje: Određivanje završnih uglova novo projektovanog površinskog kopa pri eksploataciji uljnih škriljaca sa lokaliteta Aleksinačkog ležišta programom GeoStudio 2007 - Slope/W, Projekat MNTR TR-17005 TR-1, IRM Bor br. 543, 2010.

[8] R. Rajković, D. Kržanović, R. Lekovski: Analiza stabilnosti unutrašnjeg odlagališta jalovine „Kutlovača“ površinskog kopa uglja „Potrlica“ Pljevlja softverom GeoStudio 2007, Rudarski radovi 1/2010; str. 69-74.

[9] R. Rajković, D. Kržanović, B. Rajković: Analysis of Stability During the Cleaning of Cassettes 1 and 2 of Setting Pond Filter of Waste Water Purification Facilities of Kolubara Prerada Vreoci by Software Geostudio 2007; 42. International October Conference on Mining and Metallurgy; str. 33-40, 2010.

[10] R. Lekovski, M. Mikić, D. Kržanović; Uticaj flotacijskih jalovišta na životnu sredinu Bora i mere zaštite; Mining and Metallurgy Engineering Bor, 2/2013, str. 107-116. 